\title{
State of Health Care in the Nigerian Military
}

\author{
Dabkana Theophilus Maksha ${ }^{1,2}$, Nyaku Titus Friday ${ }^{3}$, Onuchukwu Ndidi Stephen ${ }^{4}$, \\ Nyandaiti Yakubu Wilberforce ${ }^{5}$, Askira Bala Hassan ${ }^{6}$ \\ ${ }^{1}$ Department of Orthopaedics and Trauma Surgery, University of Maiduguri Teaching Hospital, Maiduguri, Nigeria \\ ${ }^{2}$ College of Medical Sciences, University of Maiduguri, Maiduguri, Nigeria \\ ${ }^{3}$ Department of Orthopaedics and Trauma Surgery, University of Maiduguri Teaching Hospital Maiduguri, Maiduguri, Nigeria \\ ${ }^{4} 7$ DIV Military Hospital and Medical Services, 7 Division Nigerian Army, Maiduguri, Nigeria \\ ${ }^{5}$ Department of Medicine, College of Medical Sciences, University of Maiduguri, Maiduguri, Nigeria \\ ${ }^{6}$ Department of Ophthalmology, University of Maiduguri Teaching Hospital and College of Medical Sciences, University of Maiduguri, \\ Maiduguri, Nigeria
}

\section{Email address:}

theophilus_dabkana@yahoo.co.uk (D. T. Maksha), fridaynyaku@yahoo.com.sg (N. T. Friday), ndidimd@yahoo.com (O. N. Stephen), ynyandaiti@yahoo.com (N. Y. Wilberforce), bhaskira@yahoo.co.uk (A. B. Hassan)

\section{To cite this article:}

Dabkana Theophilus Maksha, Nyaku Titus Friday, Onuchukwu Ndidi Stephen, Nyandaiti Yakubu Wilberforce, Askira Bala Hassan. State of Health Care in the Nigerian Military. Journal of Family Medicine and Health Care. Vol. 3, No. 3, 2017, pp. 52-55.

doi: $10.11648 /$ j.jfmhc.20170303.12

Received: March 13, 2017; Accepted: May 6, 2017; Published: October 31, 2017

\begin{abstract}
Introduction: The primary mission of any Military is to defend the territorial integrity of its country. In order to achieve this, the health of its personnel must be well taken care of to enable them can carry out their military missions during peace and wartime. Often described as the medical readiness mission, this effort involves medical testing and screening of recruits, emergency medical treatment of troops involved in hostilities, and the maintenance of physical standards of those in the armed services. This paper is aimed to highlight the lack of the above in the Nigerian Military using Diabetes mellitus as a case report. Diabetes Mellitus is a metabolic disease resulting from deficiency of insulin (absolute or relative) that prevents the body from utilizing glucose. There are essentially two types: - Type I (Insulin Dependent Diabetes Mellitus; IDDM) usually seen in children and Type II (Non-Insulin Dependent Diabetes Mellitus; NIDDM) usually seen in adults. Both types are easily diagnosed and can be managed properly once diagnosed, using injectable insulin, anti-diabetic drugs, diet or a combination. If not diagnosed however, the consequences are many. This range from death to lifelong disabilities such as blindness, chronic renal failure and loss of a limb or limb (s) [1]. The disease should not go unnoticed in a Soldier who has served his country for over thirty years. The military is known for having best medical facilities world over for its personnel and civilians who can access them. No soldier should therefore be sent to the war front without checking his or her health statues as this will affect his or her performance. This is illustrated in the case presented below. Conclusion: All military establishments worldwide, especially in the developing world, Nigeria inclusive, must make the health of its personnel a priority, even above its ordinances.
\end{abstract}

Keywords: Undiagnosed Diabetes Mellitus, Nigerian Military Personnel, Long Serving Soldier

\section{The Case}

Mr. K. Z a 52 years old Army Staff Sergeant who has served the Nigerian Army for over 35years was referred from the 7 DIV Nigerian Army Hospital to University of Maiduguri Teaching Hospital with "sun healthy blisters left foot" after staying in the bush wearing tight boots for several days while fighting the insurgents in the North East.
He has been 'healthy' all his life and cannot recall any trauma to the foot while on operation in the bush or any symptoms such as polyuria or polydypsia. He however said he recently loss weight but did attribute it to old age and the rigors of the military work. His sight has been failing him of recent.

Examination of the left foot revealed an ulcer below and anterior to the left medial malleolus, Fig. 1, which has affected the skin and muscles, discharging foul smelling pus. 
Sensation in both feet was reduced to deep pressure. We suspected diabetic foot and the RBS ordered and came out to be $36.44 \mathrm{mmol} / \mathrm{dl}$ (normal range $4.2-11.2 \mathrm{mmol} / \mathrm{dl}$ )

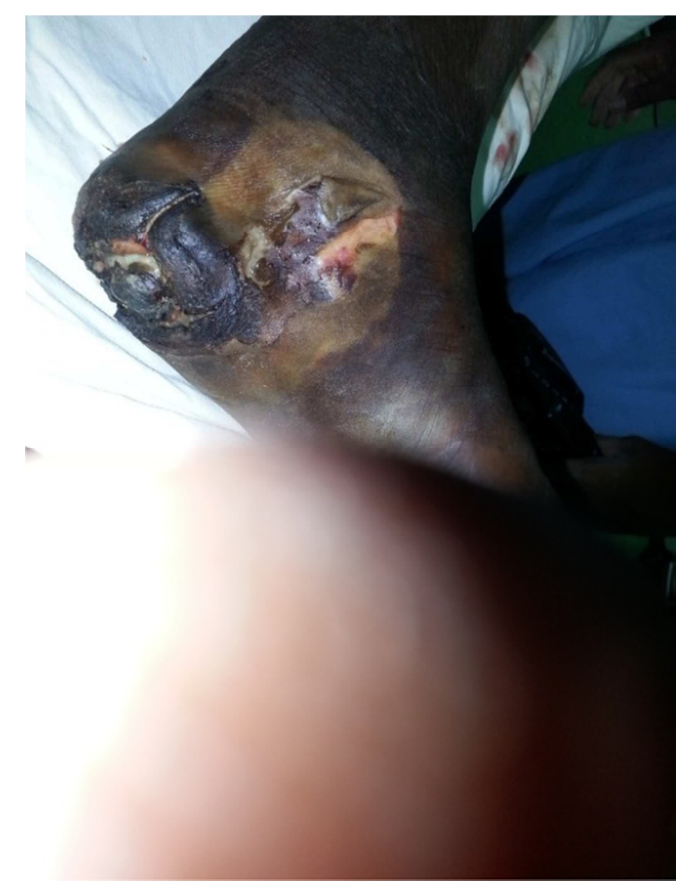

Figure 1. The foot at presentation.

A diagnosis of Diabetic foot, (Wagner Grade III) was made and patient admitted into the ward and wound dressing commenced. The following morning a fasting blood sugar (FBS) was ordered and came back to be $28.8 \mathrm{mmol} / \mathrm{dl}$, (normal range $3.5-5.4 \mathrm{mmol} / \mathrm{dl}$ ). The endocrinology unit was invited to help control the blood sugar. Renal and liver function test were normal.

Renal function test (RFT) Creatinine $=117 \mathrm{mmol} / \mathrm{L}$ (44-132)

$$
\begin{aligned}
& \text { Urea }=7.0 \mathrm{mmol} / \mathrm{L}(2.5-5.8) \\
& \text { Liver function test }(\mathrm{LFT}) \\
& \text { Total Cholesterol }=4.0 \mathrm{mmol} / \mathrm{L}(2.5-5.8) \\
& \mathrm{HDL}=1.3 \mathrm{mmol} / \mathrm{L}(1.1-1.5) \\
& \mathrm{LDL}=2.2 \mathrm{mmol} / \mathrm{L}(\leq 3.9)
\end{aligned}
$$

Patient however was anemic with a packed cell volume (PCV) of $26 \%$, with marked neutrophilia. He was transfused three pints of blood.

$$
\begin{aligned}
& \text { Full blood count PCV }=26 \% \\
& \text { Neutrophils }=73 \% \\
& \text { Lymphocytes }=25 \% \\
& \text { Monocytes }=2 \%
\end{aligned}
$$

The patient also had impaired vision in the right eye due to an immature cataract. The Ophthalmology unit was invited and is managing this complication. However, despite the FBS dropping to $9.8 \mathrm{mmol} / \mathrm{dl}$ after one month, another ulcer appeared antero-medially to the first one and the whole lesion progressed to Wagner Grade $\mathrm{V}$ and ascending, Figures $2 \mathrm{a}$ and $2 \mathrm{~b}$. Patient was counseled and had a below knee guillotine, Figure 3, after a receiving a further three pints of blood. He was commenced on daily dressing and had the stump refashioned after four weeks of Figures $4 \mathrm{a} \& \mathrm{~b}$. Patient has since been discharged home on auxiliary crutches after counseling him on how to protect the other foot. He will have his prosthesis fitted during his next visit. He was placed on oral hyperglycemic drugs (Daonil) and has so far done well.

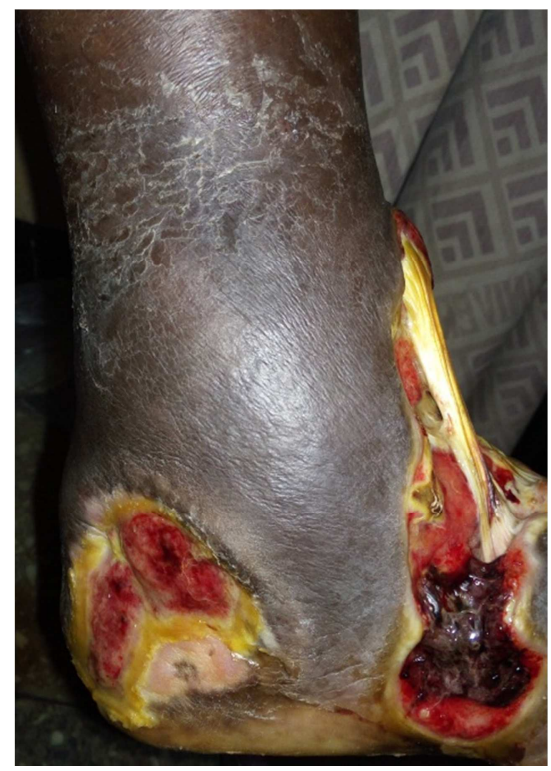

Figure 2a. The foot after one month.

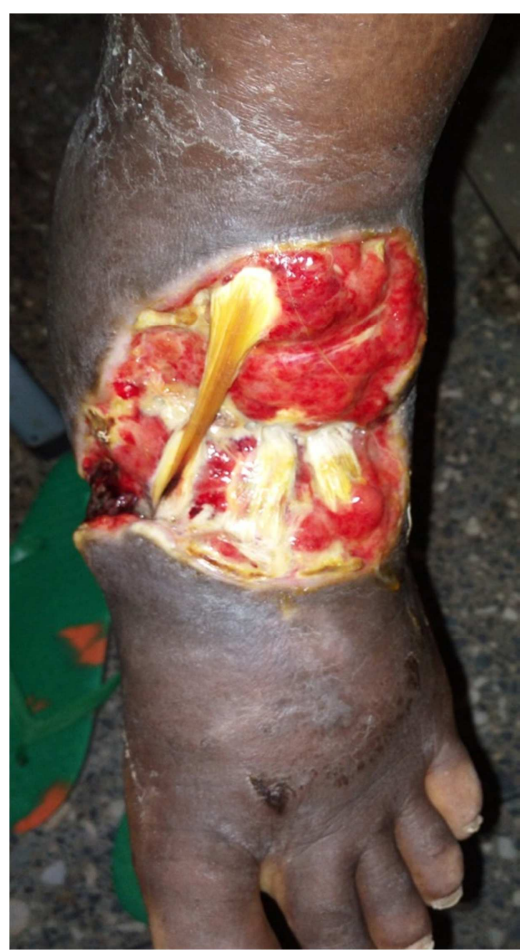

Figure $2 \boldsymbol{b}$. The foot after one month. 


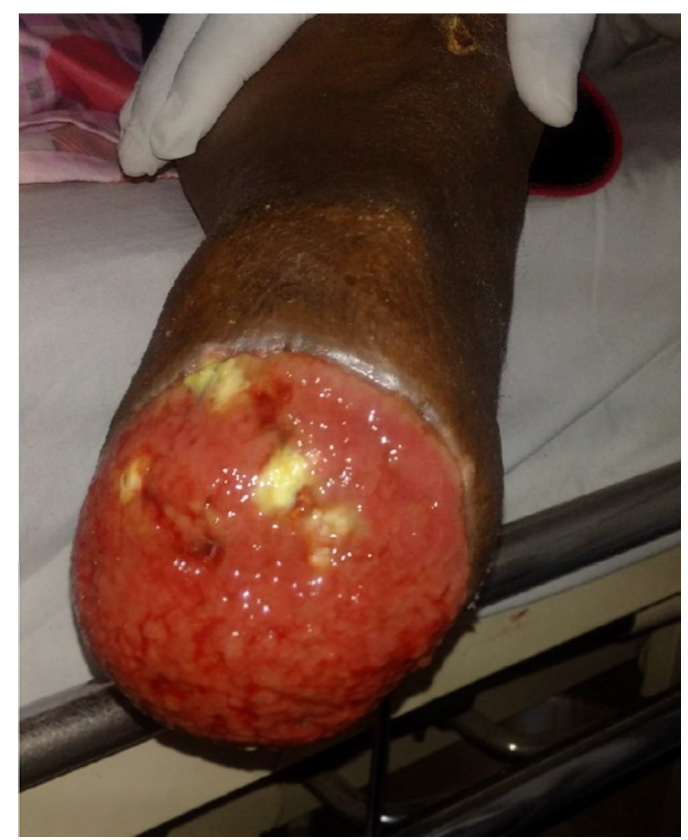

Figure 3. Clean stump before refashioning.

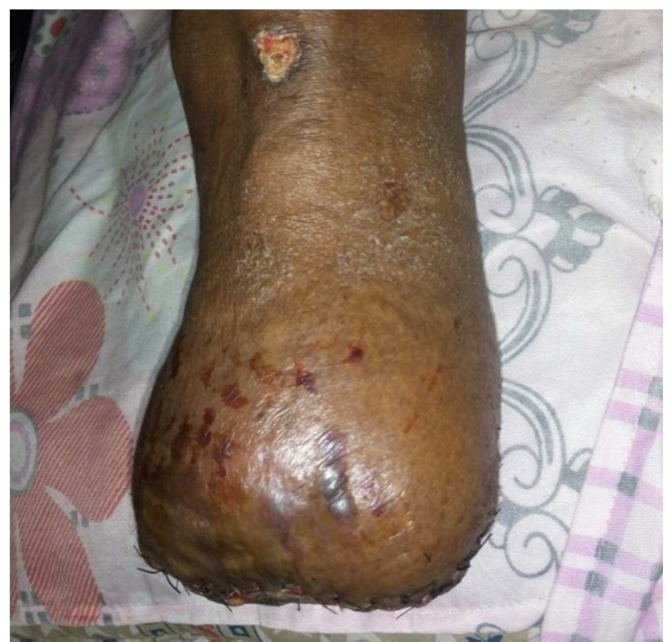

Figure 4. Refashioned stump.

\section{Discussion}

All patients with diabetes mellitus (DM) have a 25\% chance of developing diabetic foot that will lead to disabilities or amputations. Type I or insulin-dependentdiabetes mellitus (IDDM) is seen in $5-10 \%$ of patients while $90-95 \%$ of patients presenting with DM are those with type II or non-insulin dependent diabetic mellitus (NIDDM) also known as adult-onset diabetes mellitus. In type I DM, diabetic foot usually manifests after a long period of treatment but occurs early in patients with type II DM. This is because patients with type II DM usually have persistent hyperglycemia without marked clinical symptoms because they still have some insulin that metabolize some glucose preventing overt hyperglycemia and its metabolic complications from manifesting until much later in life [2]. This means that the body is unable to produce adequate insulin to meet its needs. There is Beta cell deficiency coupled with peripheral insulin resistance. By the time the disease is diagnosed in type II DM, most of the systemic damage is done, these include:-

a) Cardiac disease - this occurs due to changes in the large blood vessels leading to coronary, cerebral, and peripheral artery diseases, atherosclerosis, dyslipidemia etc.

b) Eye damage - this is termed diabetic retinopathy and occurs due to damage of the fine blood vessels of the retina in the eye due to long term exposure to high blood sugar. Also the lens can be damaged and become opaque as in this soldier.

c) Kidney damage - similar damage to small and large blood vessels of the kidneys. Initially there is proteinuria or increased outflow of protein and may lead to end stage renal disease (ESRD). This soldier was lucky not to have this.

d) Nerve damage - this can affect the arms and legs and is called stocking-glove numbness/tingling. It can also affect autonomic functions leading to impotence, erectile dysfunction, difficulty in digestion or gastroparesis etc.

e) Diabetic foot - this occurs due to peripheral nerve damage as well as blood vessel affliction due to long term diabetes. Little trauma, sores and blisters go unnoticed due to lack of sensation and peripheral vascular disease impairs healing and allows infection. This led to the complication this soldier had while at the war front. A thorough clinical evaluation would have prevented this.

These are caused by the persistent hyperglycemia they have which is thought to increase the activity of the polyol pathway, resulting in the accumulation of sorbitol and fructose in the vascular bed of nerves and decrease in $\mathrm{Na}^{+} / \mathrm{k}^{+}-$ ATPase activity ${ }^{[3]}$. There is also exposure of the nerve tissue or its vascular bed (Vasa-nervosa) to high concentration of glucose, leading to micro-vascular damage and demyelination of peripheral nerves and subsequent axonal destruction [3, 4, and 5]. The absence of C-peptide that promotes tissue perfusion, a by-product of insulin breakdown, also contributes to the ischemia in tissues and worsens the vascular and axonal damage $[6,7]$.

The cumulative effect of these processes lead to loss of sensation in the extremities in patients with type II diabetic mellitus and they can harbor a foreign body in their feet and hands without being aware of it. This causes the infections they usually present with [8]. Hyperglycemia and acidemia exacerbate impairments in humoral immunity and polymorphonuclear leukocyte and lymphocyte functions but are substantially reversed when $\mathrm{pH}$ and blood glucose levels return to normal. Although the exact level above which leukocyte function is impaired is not defined, in vitro evidence suggests a blood concentration of $200 \mathrm{mg} / \mathrm{L}$ as a possible threshold. They are also not able to notice the effect of persistent pressure which leads to ischemia and subsequent tissue necrosis that led to the problem this soldier had while wearing tight boots without feeling the pain that followed. 
What made this case special however is the fact that he had served in the Nigerian Army for over 35years and his condition was not diagnosed. He was sent to the war front with a poor vision! This was a danger to himself and his colleagues. This may underscore the healthcare services of the Nigerian Military. The defense Ministry normally has a good percentage of annual budgets. There is no reason therefore for this soldier to be in this condition he found himself. There is therefore a need for a comprehensive healthcare system for the Military in Nigeria; the MHS. All Military personnel must have access to a good healthcare system. This should extend to families of military personnel; both retired and serving [9]. The Nigerian military need to take good care of all its personnel, serving and retired, whether insured or not $[10,11]$. There is also need to train more professionals in its health sector. In fact, the Nigerian Military should be a citadel of medical knowledge and research. There is no reason to have our soldiers treated abroad while this can be achieved in the country. Collaboration with the civil society should also be encouraged.

\section{Conclusion}

All military establishments worldwide, especially in the developing world, Nigeria inclusive, must make the health of its personnel a priority, even above its ordinances. There is a need for a strong legislation for a law to entrench health care for the Military so that unfortunate incidences like that of the soldier above should not happen. The Nigerian Military should introduce a saving scheme that will take care of all its personnel even after retirement. World-standard hospitals should be built for the Military, with a full back- up of facilities like Air ambulances in each region of the country. From my experience with the Military patients, funding appears to be inadequate either absolutely or relative. This has improved of recent but more has to be done.

\section{References}

[1] Lehtinen JM, Uusitupa M, Siitonen O, Pyorala K. Prevalence of neuropathyin newly diagnosed NIDDM and nondiabetic control subjects. Diabetes 1989; 38: 1307-1313.

[2] Cameron NE, Cotter MA. The relationship of vascular damage to metabolic factors in diabetes mellitus and their role in the development peripheral nerve complications. Diabetes Metab Rev 1994; 10: 189-224.

[3] Scarpini E, Bianchi R, Moggio M, Fiori MG, Scarlato G. Decrease of nerve $\mathrm{Na}+, \mathrm{K}+$, -ATPase activity in the pathogenesis of human diabetic neuropathy. J NeurolSci 1993; 120: $159-167$

[4] Mincu I. Micro- and macroangiopathies and other chronic degenerative complications in newly detected diabetes mellitus. Med Interne Romania 1980; 18: 155-164.

[5] Wahren J, Johansson B-L, Wallberg-Henricksson H. Does Cpeptide have a physiological role? Diabetologia 1984; 37: Suppl 2: S99-S107.

[6] Ratzman KP, Raschke M, Gander I, Schimke E. Prevalence of peripheral and autonomic neuropathy in newly diagnosed type II (non-insulin-dependent) diabetes. J Diabet Complications 1991; 5: 1-5.

[7] Pirart J. Diabetes mellitus and its degenerative complications: a prospective study of 4,400 patients observed between 1947 and 1973. Diabetes Care 1978; 1:168-188.

[8] Best, Jr., Richard A. (2005-05-05). "Military Medical Care Services: Questions and Answers" Congressional Research Service. Retrieved 2008-05-23.

[9] "Mortgage Uninsured Veterans and Family Members: Who Are They and Where Do They Live?". JournalistsResource. org, retrieved June 18, 2012.

[10] Haley, Jennifer; Kenney, Genevieve M. (2012). "Uninsured Veterans and Family Members: Who Are They and Where Do They Live?" (PDF). Urban Institute. 